\title{
Review \\ Bench-to-bedside review: Latest results in hemorrhagic shock
} Martin K Angele ${ }^{1}$, Christian P Schneider ${ }^{1}$ and Irshad H Chaudry ${ }^{2}$

\author{
1Department of Surgery, Klinikum Grosshadern, Ludwig-Maximilians-University, Marchionistrasse 15, 81377 Munich, Germany \\ ${ }^{2}$ Center for Surgical Research, Department of Surgery, University of Alabama at Birmingham, University Boulevard, Birmingham, Alabama 35294-0019, \\ USA
}

Corresponding author: Irshad H Chaudry, irshad.chaudry@ccc.uab.edu

Published: 10 July 2008

This article is online at http://ccforum.com/content/12/4/218

(c) 2008 BioMed Central Ltd
Critical Care 2008, 12:218 (doi:10.1186/cc6919)

is a predictor of poor outcome in the injured patient. Early hypotension with hemorrhage in the field or at initial hospital evaluation is associated with complications such as multiple organ failure (MOF) and the development of secondary infection such as pneumonia and sepsis [4-6]. normothermia remain mainstays of therapy for patients with hemorrhagic shock. Although now widely practised as standard in the USA and Europe, shock resuscitation strategies involving blood replacement and fluid volume loading to regain tissue perfusion and oxygenation vary between trauma centers; the primary cause of this is the scarcity of published evidence and lack of randomized controlled clinical trials. Despite enormous efforts to improve outcomes after severe hemorrhage, novel strategies based on experimental data have not resulted in profound changes in treatment philosophy. Recent clinical and experimental studies indicated the important influences of sex and genetics on pathophysiological mechanisms after hemorrhage. Those findings might provide one explanation why several promising experimental approaches have failed in the clinical arena. In this respect, more clinically relevant animal models should be used to investigate pathophysiology and novel treatment approaches. This review points out new therapeutic strategies, namely immunomodulation, cardiovascular maintenance, small volume resuscitation, and so on, that have been introduced in clinics or are in the process of being transferred from bench to bedside. Control of hemorrhage in the earliest phases of care, recognition and monitoring of individual risk factors, and therapeutic modulation of the inflammatory immune response will probably constitute the next generation of therapy in hemorrhagic shock. Further randomized controlled multicenter clinical trials are needed that utilize standardized criteria for enrolling patients, but existing ethical requirements must be maintained.

\section{Introduction}

Trauma is the leading cause of death worldwide in persons aged between 5 and 44 years, and it has an impact in every community regardless of demographics $[1,2]$. Up to $50 \%$ of early deaths are due to massive hemorrhage, which is a major contributor to the dilemmas associated with traumatic injury and its care [3]. Studies have shown that hemorrhagic shock
The complex pathophysiology of hemorrhagic shock is summarized in Figure 1. Briefly, the 'shock syndrome' during massive bleeding reflects an imbalance between systemic oxygen delivery and oxygen consumption $[7,8]$. Blood loss leads sequentially to hemodynamic instability, coagulopathy, decreased oxygen delivery, decreased tissue perfusion, and cellular hypoxia [3]. Such alterations lay the foundations for subsequent development of MOF, a systemic inflammatory process that leads to dysfunction of different vital organs and accounts for high mortality rates [9]. The pathogenesis of organ injury secondary to hypovolemic insult is still incompletely understood, but both experimental studies and clinical observations suggest that leukocytes, in particular macrophages, are activated by translocated bacterial endotoxin and hypoxia/reoxygenation $[10,11]$. Activated Kupffer cells release pathologically active substances such as inflammatory cytokines, reactive oxygen species, and nitric oxide, all of which may participate in the mechanisms of hemorrhagic shock [11,12]. Moreover, increased free radical production during hemorrhagic shock and resuscitation gives rise to increased oxidative stress, which contributes to organ damage $[13,14]$. In addition, data confirm that the biologic precondition (namely sex, age, and genetic background) plays an important role in the response to hemorrhage and therapy.

It is commonly accepted that bleeding control, damage control surgery using interventional radiology, maintenance of tissue oxygenation with fluid resuscitation, coagulation support, and maintenance of normothermia represent basic

$\mathrm{AAG}=\alpha_{1}$ acid glycoprotein; $\mathrm{AMBP}=$ adrenomedullin binding protein; $\mathrm{DHEA}=$ dehydroepiandrosterone; HBOC $=$ hemoglobin-based oxygen carrier; $\mathrm{HMBG}=$ high-mobility group protein; $\mathrm{HSA}=$ human serum albumin; ICU = intensive care unit; IL = interleukin; $L R=$ lactated Ringer's; MOF = multiple organ failure; $\mathrm{NS}=$ normal isotonic saline solution; $\mathrm{rFVlla}=$ recombinant factor Vlla; $\mathrm{PCO}_{2}=$ partial carbon dioxide tension; $\mathrm{PFC}=$ perfluorocarbon; $\mathrm{PO}_{2}=$ partial oxygen tension; $\mathrm{TNF}=$ tumor necrosis factor. 


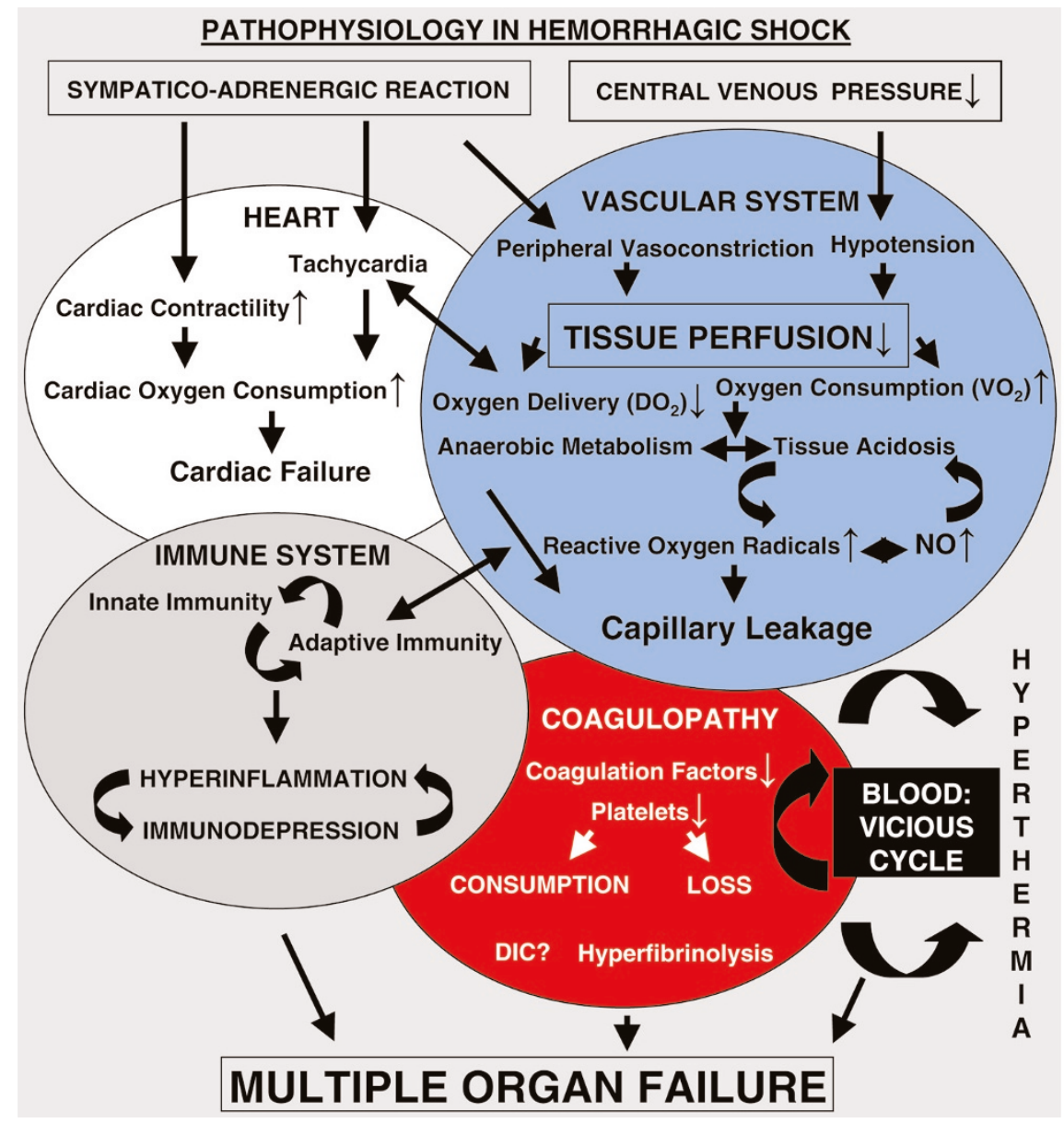

Illustration of the pathophysiological changes in hemorrhagic shock. DIC, disseminated intravascular coagulopathy; NO, nitric oxide.

support measures in hemorrhage care that can pre-empt or rapidly reverse hypoxemia, hypovolemia, and the onset of shock [15-17]. Regarding current resuscitation strategies, management of hemorrhagic shock in the USA and Europe relies heavily on blood replacement and fluid volume loading to restore tissue perfusion [15-17]. Although resuscitation strategies for severely injured patients who present with shock have improved greatly, these transfusions are associated with development of MOF, and increased intensive care unit (ICU) admissions, ICU and hospital length of stay, and mortality [18-21]. Although prevention of injury is plausible and desirable, the complications of traditional treatment modalities should be recognized and further clinical trials conducted to evaluate potential new therapeutic strategies.

\section{Biologic precondition: sex, age, and genetics}

It was recently shown that the biologic precondition of individuals (namely sex, age, and genetics) has a profound impact on immune response after trauma/hemorrhage [22]. Although sex-specific differences in susceptibility to and morbidity resulting from sepsis have been observed in several epidemiologic and clinical studies [23-26], little attention has been given to sex-specific differences in the immune response to trauma and severe blood loss. Furthermore, experimental studies investigating alterations in immune functions after trauma have historically used male laboratory animals. In this respect, a number of studies have demonstrated diverse immune responses in male and female mice after trauma/hemorrhage [27]. Higher plasma estradiol and/or higher plasma prolactin levels might contribute to enhanced immune response after hemorrhage in pro-estrus females. Administration of estrogen in castrated male mice, even with testosterone supplementation, improved the depressed immune responses after trauma/hemorrhage [28]. Moreover, treatment of intact male mice with estradiol normalized the depressed immune responses after trauma and hemorrhage, and improved the survival rate after subsequent sepsis [29]. A prospective study conducted in more than 4,000 trauma patients recently demonstrated that hormonally active women tolerate trauma/shock better than men [30]. 
Dehydroepiandrosterone (DHEA) has also been reported to have estrogenic effects [31]. Treatment of male mice with DHEA after trauma and blood loss prevented immunosuppression and decreased susceptibility of those mice to subsequent sepsis [32]. Because DHEA is used clinically as a long-term immuno-enhancing drug, this hormone might represent a useful therapy for preventing immunodepression in surgical patients. Recently, DHEA was found to stimulate the release of proinflammatory cytokines from human peripheral blood mononuclear cells after major abdominal surgery in vitro [33]. A prospective clinical trial, however, must be conducted to validate the immunoprotective effects of DHEA in patients after severe blood loss. In addition to female sex steroids, the lower levels of male hormones in female animals as compared with males might also contribute to the divergent immunoresponsiveness observed after injury and blood loss. Depletion of testosterone by castration before hemorrhage or by administration of flutamide after hemorrhage and resuscitation normalized the depressed immune responses and maintained cardiovascular function in male animals [27]. Because flutamide is used clinically without major side effects, this might represent a clinically relevant therapeutic approach in trauma victims.

In addition, age must be taken into account when extrapolating experimental results into clinics. This is because recent studies have indicated that aged male and female mice exhibit different sex-specific immune responses than do young animals [34,35].

The availability of improved techniques for molecular diagnosis has allowed investigation of the roles played by genetic variations in the inflammatory responses to trauma/hemorrhage. New diagnostic tools have revealed the importance of genetic background on pathophysiological mechanisms and their modulation after shock [36]. In this respect, clinical studies revealed that IL-6-174G/C polymorphism is associated with increased severity of post-traumatic systemic inflammatory response syndrome [37], suggesting an adverse outcome in those patients. Furthermore, it has been shown that the 1,082 $\mathrm{IL}-10$ polymorphism is associated with acute respiratory failure after major trauma [38]. In addition, specific genetic variations in the mitochondrial DNA that influence energy production and free radical generation appear to increase the risk for inhospital mortality after severe injury [39]. To date, genomics findings in patients have only been used as prognostic factors, and have not been used to direct therapy after hemorrhage. Larger scale studies are needed to improve our understanding of how genetic variability influences responses to posttraumatic complications and pharmacotherapy.

In summary, the above-mentioned studies collectively suggest that sex, age, and genetics reveal potential clinically relevant therapeutic options. However, several promising experimental approaches such as tumor necrosis factor (TNF) antibody and others $[9,40]$ have not been successful in the clinical arena for the treatment of shock because of the redundancy in the inflammatory pathways. Other pathways and cytokines may activate and/or inhibit the system at the same point, and different mediators may function as codeterminants of the inflammatory system in parallel. Therefore, modulating rather than neutralizing a cytokine is the desired objective in the treatment of trauma victims. At present, however, such strategies are in the early stages of investigation. Furthermore, because of the complexity of genetic patterns, it remains difficult to apply genetic preconditions to develop individualized hemorrhage therapy.

\section{Monitoring}

In patients who have or have had hemorrhagic shock, heart rate, urine output, capillary refill, systolic blood pressure, and mental status represent the basic parameters that define cardiovascular stability. Appropriate additional monitoring primarily includes arterial pressure (via arterial catheter), arterial hemoglobin oxygen saturation (via pulse oximetry), and central venous pressure (via central venous line) monitoring. Measurement of arterial blood gases with lactate and base deficit determinations indicate the severity of shock, and serial hemoglobin measurements allow assessment of ongoing bleeding [15-17]. The goal is to return blood pressure and heart rate to normal, and establish urine output while maintaining central venous pressure in a moderate range (8 to $15 \mathrm{mmHg}$ ) [41]. How specific those traditional parameters are in the clinical arena and which values represent the end-point that should be reached are still under extensive discussion. In particular, restoration of vital signs to normal while uncontrolled hemorrhage is ongoing may be detrimental to the patient, causing volume overload and rebleeding, and thus creating a vicious cycle of events. Therefore, hypotensive resuscitation, whereby safe but subnormal blood pressure is achieved, may represent a future strategy to avoid the problems that result from use of traditional resuscitation strategies $[2,42]$.

Studies indicate that oxygen debt and lactate appear to play important roles in defining the severity of hemorrhagic shock; thus, normalizing these parameters might be appropriate therapeutic end-points $[41,43]$. Currently, indirect measurement techniques that reflect cellular oxygen utilization and perfusion, either systemically (lactate and base deficit) or locally (gastric intramucosal $\mathrm{pH}$ and microdialysis), are primarily used [44]. Experimental and clinical studies have indicated that evaluation of tissue perfusion with measurement of cutaneous and transcutaneous partial oxygen tension $\left(\mathrm{PO}_{2}\right)$, skeletal muscle $\mathrm{PO}_{2}$, gastric tonometry, $\mathrm{pH}$ determination using fiberoptic technology, infrared spectroscopy, and minimally invasive monitoring with measurement of bladder mucosa $\mathrm{pH}$ and partial carbon dioxide tension $\left(\mathrm{PCO}_{2}\right)$ may represent new techniques for monitoring patients with hemorrhagic shock [45-50]. However, at present these technologies require the use of relatively complex or invasive methodologies. Moreover, newer experimental results demon- 
strate that the findings of continuous monitoring of skeletal muscle and subcutaneous $\mathrm{pH}, \mathrm{PO}_{2}$, and $\mathrm{PCO}_{2}$ - as potential surrogates of impaired tissue metabolism - vary among tissues and according to the phase of hemorrhage or resuscitation [51]. New bioimpedance technology to monitor cardiac output has successfully been applied to direct trauma resuscitation in the emergency department setting [52]. Buccal $\mathrm{PCO}_{2}$ measurement and high intensity focused ultrasound also represent new and promising techniques; they have proven to be practical and reliable measurements in the diagnosis of circulatory failure states and to serve as useful indicators of the severity of these states [53,54].

Although these techniques may move the end-points of hemorrhagic shock to the organic, cellular, and subcellular levels, large clinical studies are scarce. More precise techniques for monitoring hemorrhagic shock are thus required, which can be easily and repeatedly applied in the clinical setting.

It is well known that shock initiates dysfunctional inflammation that causes MOF. Resuscitation is a vital intervention that decreases the severity of the shock insult, but current strategies are not directed at modulating the immune response; in fact, they may worsen it. Those parameters that are routinely monitored in the clinical setting do not adequately reflect the immune status of the patient (hyperinflammation versus immunoparalysis), which is important when starting traditional and immunomodulatory therapies.

Proinflammatory cytokine levels correlate with prognosis; in this respect, elevated levels of TNF- $\alpha, \mathrm{IL}-1$, and IL- 6 in plasma have been well described in both animal experiments [55-57] and patient studies [58-62] after trauma and severe blood loss. Measurement of soluble inflammatory parameters can be routinely performed in many institutions. However, there are several important limitations because determination of soluble inflammatory mediators does not entirely reflect cytokine tissue levels; they therefore may not represent a good indicator for the extent of tissue inflammation and organ damage. Furthermore, a single mediator may not be an adequate indicator of the inflammatory response because of the complexity of the underlying pathways. In this regard, newer biotechnological methods may be employed to identify immune cell surface markers (HLA-DR); expression of proinflammatory and anti-inflammatory mediators at the immune cell level (intracellular cytokine staining, cytokine secretion assay) and cytokine gene expression via array technology may demonstrate new tools for diagnosis and monitoring of critically ill patients with bleeding [63-65]. Nonetheless, proinflammatory cytokine levels might soon become important in the management of trauma patients in the ICU. Knowledge of the patient's cytokine levels may yield some indicator of the intracellular milieu and possibly provide insight into the cellular changes taking place. This information might provide the clinician with a better understanding of how to treat such a critically ill trauma patient. However, the techniques require refinement to allow rapid and online measurement of cytokines before the full benefit of such information can be effectively translated into better management of trauma patients.

Although various cytokine therapies in critically ill patients have not yet yielded satisfactory results, the lack of beneficial effect might be related to timing and dose of anticytokine administered. It is our hypothesis that total blockade/ neutralization of cytokines will not be helpful to the host. Rather, modulation of cytokine production/release by immune cells (macrophages and $\mathrm{T}$ cells), leading to restoration of cellular homeostasis, might be a better way to decrease the susceptibility of trauma victims to subsequent sepsis and infection. However, further basic research to investigate inflammatory pathways and identify co-determinants will represent an inescapable prerequisite for progress in this area.

\section{Resuscitation}

For the past four decades, the standard approach to the trauma victim who is hypotensive from presumed hemorrhage has been to infuse large volumes of isotonic crystalloids as early and as rapidly as possible $[15-17,66]$. The goals of this treatment strategy are rapid restoration of intravascular volume and vital signs, and maintenance of vital organ perfusion. The most efficient solution for use in resuscitation is still under debate. Lactated Ringer's (LR) and normal isotonic saline solution (NS) remain the most commonly used isotonic fluids [16]. Although colloid solutions, including hyperosmolar colloid and hypertonic electrolyte compounds, have been approved for use as volume expanders, their administration is still under debate in the USA and Europe $[16,17]$.

It is generally believed that LR is better than NS because it provides a better buffer for metabolic acidosis, but investigators have still not validated this hypothesis. Experimental studies have revealed that resuscitation with NS in the setting of massive hemorrhage requires significantly greater volume and is associated with increased physiologic derangements (for example, hyperchloremic acidosis and dilutional coagulopathy) and higher mortality as compared with LR $[67,68]$. In contrast, results from a recent preclinical study [69] indicated increased endothelial dysfunction after resuscitation with LR alone. Alternative crystalloid solutions have also been developed (for instance, Ringer's ethyl pyruvate) that exhibit anti-inflammatory properties [70], but a recent experimental study [71] showed that resuscitation with Ringer's ethyl pyruvate was not associated with improved early hemodynamics or tissue energetics as compared with LR.

The first prospective randomized controlled trials were initiated during the mid-1970s to compare semisynthetic colloid solutions (gelatins, dextrans, and hydroxyethyl starches) as plasma volume expanders in critically ill patients, with pulmonary dysfunction as the primary end-point because 
excessive administration of isotonic fluids resulted in a new entity termed 'shock lung' [72-74]. However, the results of the studies were not definitive because of differences in study design, small numbers of patients included, heterogeneous populations, differences in resuscitation end-points, and difficulties in defining pulmonary dysfunction. Nonetheless, if mortality is used as the end-point and the data are subgrouped, then the use of crystalloids in trauma patients is associated with improved survival [74]. Several additional systematic reviews were conducted, but the large variation in patient populations impeded clear interpretation. It was finally concluded that because there was no evidence that one colloid solution was safer than another, and because no reduction in risk for death was evident in critically ill patients, continued use of these agents in these patients could not be justified outside the setting of randomized controlled trials $[74,75]$. Although experimental results indicated that resuscitation with LR and colloids have equivalent effects on indices of inflammation in the lungs [76], reported data from several studies conducted in critically ill patients have indicated that use of colloid solutions has a significant impact on hemorrhage, hemostasis, and inflammatory response [77-79].

Because human serum albumin (HSA) is responsible for $80 \%$ of the colloid osmotic pressure of plasma, it may represent a possible resuscitation fluid in hemorrhagic shock. However, a meta-analysis of studies using albumin-containing fluids revealed that their use is associated with a 1.68-fold increase in the relative risk for death when compared with a crystalloid solution [80]. This effect is related to an increased leakage of albumin into the extravascular spaces, worsening the edema that takes place during hypovolemia and exacerbating respiratory and cardiac failure [81]; possible contamination of the preparation with prion/viral components poses additional risk to users. Nonetheless, in a large-scale clinical trial conducted in Australia and New Zealand, in which 4\% albumin was compared with NS for intravascular fluid resuscitation, no difference in mortality was reported [82]. Recombinant HSA may offer a new perspective, because reported data indicate a high retention rate in circulating blood and lower vascular permeability than with the native HSA [81]; however, potential immunological alteration after the use of recombinant HSA in critically ill patients must be investigated.

The most recent studies of hemorrhagic shock and resuscitation suggest that our current protocols are far from ideal, and may in fact be harmful [41]. During the past decade, several studies have investigated different strategies in resuscitation. In the 1980s the first report of use of hypertonic saline was published [83]. Small volume hypertonic saline was shown to be as effective as large volume crystalloids in expanding plasma volume; enhancing cardiac output and microcirculation; limiting acute lung injury, neutrophil activation, and red blood cell injury; and restoring renal performance in animals with hemorrhagic shock
$[84,85]$. However, the increased microcirculation after resuscitation with hypertonic saline in animals was associated with increased bleeding, but mortality was model dependent and the best survival was obtained when saline was given with high-volume crystalloid [83]. A further experimental study demonstrated enhanced resuscitation effects with a combination of hypertonic saline and dextran [86]. Several clinical studies followed, and a meta-analysis of those studies [87] revealed that hypertonic saline is not better than the current standard of care, namely isotonic fluids, but the combination of hypertonic saline with dextran might be superior. Trauma patients with combined head injury and hemorrhagic shock profited the most because data showed that resuscitation with this combination increased cerebral perfusion, and decreased intracranial pressure and brain edema. Therefore, hypertonic saline solutions have evolved as an alternative to mannitol. However, caution is advised with high osmolar loads because they carry increased risk for potentially deleterious consequences of hypernatremia, or they may induce osmotic blood-brain barrier disruption, with possibly harmful extravasation of the hypertonic solution into the brain tissue [88]. Moreover, a randomized controlled trial [89] indicated that prehospital resuscitation with hypertonic saline in patients with hypotension and severe traumatic brain injury led to almost identical neurological function 6 months after injury as in patients who received conventional fluids. Nevertheless, investigation of the optimal resuscitation fluid is an ongoing field of interest.

Other current experimental data indicate that titrated hypertonic solutions combined with $10 \%$ hydroxyethyl starch are superior to LR without increasing blood loss [90]. Moreover, the optimal fluid composition appears to play an important role because a single bolus of $3 \%$ saline with $6 \%$ dextran-70 was able to raise mean arterial pressure and tissue oxygen saturation while attenuating post-traumatic hypercoagulability in an animal model of uncontrolled hemorrhagic shock [91]. Further benefit may result from the combination of hypertonic saline and the immunoactive phosphodiesterase inhibitor pentoxifylline [92]. Resuscitation with this combination has been shown to prevent lung injury and bacterial translocation, downregulate inducible nitric oxide synthase, and decrease end-organ damage [93-95]. However, those resuscitation strategies must prove their efficacy in the clinical arena, and therefore further randomized clinical trials are needed. In this regard, two prehospital intervention trials were recently successfully designed and implemented to compare hypertonic saline resuscitation with or without dextran versus conventional isotonic resuscitation in patients with hypovolemic shock or traumatic brain injury [96]. The results of these studies will hopefully advance and improve the early care of severely injured patients.

\section{Transfusion}

Early administration of blood is one potential treatment to decrease the need for massive crystalloid solution in 
Table 1

\begin{tabular}{|c|c|c|c|c|}
\hline Category & Product & Type & MW (Daltons) & Phase of testing \\
\hline Perfluorocarbons & Oxygent ${ }^{\mathrm{TM}}$ & Perfluoroctylbromide & 450 to 500 & $\begin{array}{l}\text { Up to clinical phase III, } \\
\text { discontinued }\end{array}$ \\
\hline \multirow[t]{4}{*}{$\begin{array}{l}\text { Hemoglobin-based } \\
\text { oxygen carrier }\end{array}$} & HemAssist $^{\mathrm{TM}}$ & Diaspirin-crosslinked hemoglobin (human) & 65,000 & $\begin{array}{l}\text { Up to clinical phase III, } \\
\text { discontinued }\end{array}$ \\
\hline & Hemopure ${ }^{\mathrm{TM}}$ & Polymerized bovine hemoglobin (bovine) & 250,000 & Up to clinical phase III \\
\hline & Polyheme ${ }^{T M}$ & $\begin{array}{l}\text { Pyridoxylated glutaraldehyde-polymerized } \\
\text { hemoglobin (human) }\end{array}$ & 150,000 & Up to clinical phase III \\
\hline & Hemospan ${ }^{\mathrm{TM}}$ & $\begin{array}{l}\text { Maleimide-activated polyethylene-glycol- } \\
\text { modified hemoglobin (human) }\end{array}$ & 95,000 & $\begin{array}{l}\text { Up to clinical phase II, phase } \\
\text { III planned }\end{array}$ \\
\hline Hemoglobin vesicles & Oxygenix ${ }^{\mathrm{TM}}$ & Hemoglobin containing liposomes (OXY-0301) & Unpublished & Experimental, up to phase I \\
\hline
\end{tabular}

Presented are the physiochemical characteristics and state of clinical research on artificial oxygen carrier. The manufacturers are as follows: Oxygent $^{\mathrm{TM}}$, Alliance Pharmaceutical Corp., San Diego, CA, USA; HemAssist ${ }^{\mathrm{TM}}$, Baxter Healthcare, Round Lake, IL, USA; Hemopure ${ }^{\mathrm{TM}}$, Biopure Corp., Cambridge, MA, USA; Polyheme ${ }^{\mathrm{TM}}$, Northfield Lab Inc., Evanston, IL, USA; Hemospan ${ }^{\mathrm{TM}}$, Sangart Inc., San Diego, CA, USA; and Oxygenix ${ }^{\mathrm{TM}}$, Oxygenix Co. Ltd., Tokyo, Japan.

hemorrhagic shock; however, the limited supply of stored blood and potential adverse effects make this option logistically difficult and possibly harmful [15-17]. In addition, potential infectious complications (hepatitis, HIV, and bacterial contamination), immune suppression [97-99], and metabolic complications (hyperkalemia, hypocalcemia, and citrate toxicity) and risk for mistransfusion [100] are well documented. Transfusion-related risks include possible development of MOF, increased ICU admissions and length of stay, increased hospital length of stay, and mortality [18-21]. As a result, intensive investigations were conducted to develop a new artificial oxygen carrier (Table 1).

Perfluorocarbons (PFCs) are an interesting development, representing simply constructed molecules from cyclic or straight-chain hydrocarbons with hydrogen atoms replaced by halogens (fluorine or bromide), which are characterized by a linear relationship between arterial $\mathrm{PO}_{2}$ and oxygen content [101]. PFCs are insoluble in water and must be emulsified for intravenous administration. The oxygen release from PFCs to tissue is almost complete in the presence of a high $\mathrm{PO}_{2}$ gradient between arterial blood and tissue. However, administration of PFCs is restricted to low dosages because studies have indicated that PFC emulsion droplets are rapidly taken up by the reticuloendothelial system and subsequently cause immunosuppression [101,102]. Experimental studies have demonstrated that use of PFCs allows the extension of acute normovolemic anemia (hematocrit 21\% to $8 \%$ ) without signs of impaired tissue oxygenation or compromised myocardial contractility $[103,104]$. Clinical application of PFCs has been shown to maintain gastrointestinal tissue oxygenation at hemoglobin levels below $7 \mathrm{~g} / \mathrm{dl}$, to delay the interval until transfusion of allogenic blood was required, and to decrease the number of transfused red blood cell units in patients undergoing cardiac and noncardiac surgery
[105-107]. However, enrollment in a phase III study investigating administration of PFCs in cardiac surgical patients was discontinued because of an increased rate of neurological complications. A recent multicenter phase III study conducted in patients undergoing noncardiac surgery and suffering high-volume blood loss demonstrated an increased incidence of postoperative ileus, in addition to typical mild side effects (flu-like symptoms, fever, headache, nausea, and myalgia) $[101,107]$.

Hemoglobin-based oxygen carriers (HBOCs) for trauma resuscitation may provide a workable compromise, because their use in experimental studies of severe hemorrhagic shock demonstrated stabilization of hemodynamic status and tissue oxygenation, and decreased mortality [108-111]. Moreover, the postischemic interactions between leukocytes and endothelium were attenuated by infusion of human and bovine HBOC [112-114]. Surprisingly, an interim analysis of clinical application of the long-term favorite HBOC diaspirincrosslinked hemoglobin (HemAssist ${ }^{\mathrm{TM}}$; Baxter Healthcare, Round Lake, IL, USA) for treatment of severe traumahemorrhagic shock [115] demonstrated increased rates of 24-hour and 48-hour mortality; therefore, the trauma study was discontinued. In contrast, pyridoxylated glutaraldehydepolymerized hemoglobin (PolyHeme ${ }^{\mathrm{TM}}$; Northfield Labs Inc., Evanston, IL, USA) proved to be an effective resuscitation fluid in 171 patients suffering from massive hemorrhage [116]. Although experimental studies indicated that administration of HBOC-201 (polymerized bovine hemoglobin; Hemopure $^{\mathrm{TM}}$; Biopure Corp., Cambridge, MA, USA) in hemorrhagic shock is effective and improved outcome, the potential vasoconstrictive properties of all HBOCs must be taken into account if their use is considered [117-120]. The clinical impact is not yet fully understood, but possible underlying mechanisms include scavenging of nitric oxide, 
augmented release of endothelin, and stimulation of endothelin receptors and adrenoreceptors [117-120]. In this respect, a nonvasoactive HBOC was recently developed (maleimideactivated polyethylene-glycol-modified hemoglobin; Hemospan ${ }^{\mathrm{TM}}$ ) and proven to provide sufficient tissue oxygenation at the microcirculatory level in an experimental model of hemorrhagic shock [121]. Hemospan ${ }^{\mathrm{TM}}$ (Sangart Inc., San Diego, CA, USA) has finished testing in phases I and II, and a phase III prehospital trial is underway [122].

Another promising development representing hemoglobin vesicles involves use of phospholipid vesicles (liposomes) that encapsulate purified human hemoglobin. Because experimental studies in hemorrhagic shock have shown that fluid resuscitation with hemoglobin vesicles maintained systemic oxygenation and did not induce either vasoconstriction or activation of the immune system, their further investigation in hemorrhagic shock is needed [123,124].

\section{Vasoactive substances}

The primary goal of treatment in hemorrhagic shock is prompt restoration of tissue perfusion. However, this concept has come under debate, particularly in uncontrolled and advanced hemorrhage [125]. In the initial phase of hemorrhagic shock, vasopressors are widely used to maintain blood pressure while resuscitation is ongoing. However, during the late phase of hemorrhagic shock, replacement of fluids and blood may become ineffective, even when supported by traditional vasopressors such as norepinephrine, which indicates a paralyzed vasculature [125].

Theorized mechanisms of vasomotor paralysis partly involve tissue acidosis, hypoxia, and ATP depletion. The ATPsensitive potassium channels in particular represent an important regulator of the vascular tone of arterioles, and thus blood supply of most organs is regulated in part via these channels $[126,127]$. However, if too many organs try to obtain additional perfusion, which is simply not possible during severe shock, then regional perfusion decreases and a vicious shock cycle results. Adrenal insufficiency in hemorrhagic shock may also represent a contributing factor [128]. Most recently, vasopressin - a recognized endogenous stress hormone - has been found to represent a potential drug therapy that can prevent this vicious shock cycle. Experimental studies demonstrated that vasopressin can inhibit both ATP-sensitive potassium channels and nitric oxide induced accumulation of cGMP [129]. In critically ill patients such as those suffering out-of-hospital cardiac arrest or septic shock, vasopressin has been identified to be highly supportive [130,131]. Experimental studies conducted in trauma and hemorrhagic shock have also indicated that administration of vasopressin minimized fluid resuscitation volume, improved cardiopulmonary parameters, led to a markedly improved neurologic outcome if brain injury was present, and improved survival [132-134]. Regarding potential benefits in patients with hemorrhage, only case reports are currently available, but a multicenter trial was recently initiated [135]. A recent retrospective data analysis revealed that caution should be exercised with vasopressor treatment in hemorrhagic shock, because increased mortality in blunt injured adults with hemorrhagic shock was observed after use of vasopressors as compared with aggressive early crystalloid resuscitation [136]. However, that study had several limitations. Specifically, it was a secondary analysis, and those patients who required early vasopressor treatment were older, more severely injured, had worse initial shock parameters, and required greater resuscitation after injury, more invasive monitoring, and treatment in the ICU. Therefore, further prospective randomized trials are needed to address this issue adequately and identify potential confounders.

In contrast, a newly identified vasodilatory peptide, namely adrenomedullin, which is depressed after severe blood loss because of downregulation of adrenomedullin binding protein (AMBP)-1 [137], acts as a circulating hormone that elicits various biologic activities in a paracrine and autocrine manner. Human AMBP-1 has been shown to potentiate adrenomedullin-induced vascular relaxation in the aorta under normal and pathophysiological conditions [138]. Experimental studies revealed that administration of adrenomedullin in combination with AMBP-1 in hemorrhagic shock improved cardiac performance and tissue perfusion, attenuated hepatic and renal injury, prevented metabolic acidosis, downregulated proinflammatory cytokines, and reduced mortality $[137,139,140]$. The beneficial effect of adrenomedullin/ AMBP-1 is associated with downregulation of endothelin-1, which is normally upregulated in hemorrhagic shock [140]. However, clinical studies are necessary to evaluate the precise underlying mechanisms and potential benefits of adrenomedullin and its binding protein in traumatic injury and hemorrhagic shock.

\section{Coagulation support}

Excessive hemorrhage is associated with coagulopathy, which is proportional to the volume of blood loss [141]. Analysis of adult patients receiving more than 10 units of red blood cells in a major trauma center identified acidosis $(\mathrm{pH}$ $<7.1)$, hypothermia $\left(<34^{\circ} \mathrm{C}\right)$, Injury Severity Score above 25 , and systolic blood pressure below $70 \mathrm{mmHg}$ as independent risk factors for coagulopathy [142]. Nonetheless, coagulopathy is generally multifactorial and additional contributing factors include the following [143]: hemodilution, hypovolemia, hypothermia-associated platelet dysfunction, activation of the coagulation and fibrinolytic cascades, endothelial cell damage leading to disseminated intravascular coagulation, impaired hepatic synthesis of coagulation factors, decreased clearance of activated factors, and release of tissue factors into the circulation. In addition to rewarming, coagulation factor replacement with fresh frozen plasma, prothrombin complex concentrates, fibrinogen concentrates, antifibrinolytics (tranexamic acid and $\varepsilon$-aminocaproic acid), 
and platelet concentrates play an important role in the management of bleeding $[15,17,143]$.

An additional attractive candidate for maintaining coagulation in hemorrhagic shock is recombinant factor VIla (rFVIla), which has been approved for treatment of bleeding in patients with hemophilia or vitamin K-antagonist therapy [144]. Supraphysiological doses of rFVIla bind to phospholipid structures of activated platelets at the site of injury, which may underlie the localized effects of this compound [144]. In various animal models of hemorrhage, rFVlla has been shown to be an effective procoagulant adjunct for controlling bleeding $[145,146]$. In addition to numerous promising case studies that reported decreased mortality in patients with severe trauma [144,147], only one randomized clinical trial is available at present [148], which indicated beneficial effects in the treatment of coagulopathic bleeding after trauma. Although a recent systematic review of the efficacy of rFVIla in treatment of bleeding in patients without hemophilia [149] revealed no difference in thromboembolic events compared with placebo, there was also no difference observed for death, total blood loss, and transfusion. Currently, the rationale for using $\mathrm{rFVlla}$ to treat massive bleeding is only as an adjunct to the surgical control of bleeding if conventional therapies have failed [150]. Although European and US recommendations indicate that $\mathrm{rFVlla}$ should be used in massive bleeding $[15,17]$, further randomized clinical trials are warranted. A major randomized double-blind study is currently being conducted in the USA, and the results will hopefully verify the therapeutic benefits of rFVlla in traumatic hemorrhage as well as its potential adverse effects.

\section{Future therapeutic approaches}

Based on advances in the characterization of pathophysiological mechanisms and identification of new mediators after hemorrhagic shock, new therapeutic strategies have been developed in clinically relevant animal models. An incomplete selection of promising approaches is presented in the following discussion. Clinical studies using these agents must be conducted in the future to determine their effectiveness in patients.

High-mobility group protein (HMGB) 1 has been identified as a late-acting mediator of lipopolyaccharide-induced or sepsisinduced lethality in mice [151,152]. Moreover, HMGB1 is a cytokine-like molecule that can promote TNF release from mononuclear cells [153]. In addition, HMGB1 is actively secreted by immunostimulated macrophages [154]. Similarly, elevated plasma levels of HMGB1 were evident in patients with trauma-induced hemorrhagic shock [155]. The above studies collectively suggest that HMGB1 is involved in the disease process after blood loss in patients and animals. In view of this, anti-HMGB1 neutralizing antibodies used after hemorrhagic shock and resuscitation in a clinically relevant animal model demonstrate improved survival rates [155]. Moreover, anti-HMGB1 neutralizing antibodies decreased bacterial translocation to mesenteric lymph nodes, associated with lower circulating levels of IL-6 and IL-10. AntiHMGB1 neutralizing antibodies warrant further evaluation as a therapeutic option in patients who have suffered trauma and hemorrhage.

$\alpha_{1}$ Acid glycoprotein (AAG), one of the acute phase proteins, has been shown to protect endothelial barrier function and to decrease leukocyte-endothelium interaction following adverse circulatory conditions $[156,157]$. Endothelial cell dysfunction, capillary leakage, and leukocyte accumulation play key roles in initiating the pathophysiological mechanisms that become active after trauma and hemorrhage. In view of this, studies were conducted in which AAG was administered during resuscitation after trauma and blood loss in rodents [158]. The results indicate that AAG reduced edema formation, capillary leakage, and neutrophil accumulation after trauma and blood loss. Although the precise underlying mechanisms for the protective effects of AAG under those conditions are unknown, the findings suggest that various mediators are affected. Because there are many redundant pathways for mediators, AAG appears to be a promising adjunct in the clinical arena.

Additional pathways and mediators that might yield promising therapeutic options are hydrogen sulfide and the use of its blocker [159]. Additionally, blockade of reactive oxygen species with hemigramicidin-TEMPO conjugate (a novel mitochondria-targeted antioxidant) or 5-aminoisoquinolinone (a poly-ADP-ribose synthase inhibitor) may provide cytoprotection during hemorrhagic shock and after resuscitation [160,161]. Moreover, complement depletion or inhibition demonstrated beneficial effects in animal models of hemorrhage, and therefore they represent an interesting novel treatment option [162] in the clinical arena.

Studies have also shown that the use of $17 \beta$-estradiol (estrogen) after trauma/hemorrhage in male or ovariectomized female rodents improved cardiovascular and immunologic functions and decreased mortality from subsequent sepsis [22,27,163-170]. Because only a single dose of estrogen was used, this was not a hormone replacement therapy and thus should be considered as a safe and effective adjunct for maintaining cardiovascular and immunologic responses following low-flow conditions in male and female trauma patients. Studies have also shown that flutamide (androgen receptor antagonist) after trauma/hemorrhage in males increased aromatase activity, increased estrogen levels, upregulated estrogen receptors, and improved cell/organ function under those conditions [171,172]. Additional studies have shown that the use of DHEA, metoclopramide, prolactin, or progesterone [172-174] as adjuncts to resuscitation after trauma/hemorrhage also produced salutary effects on cardiovascular and immunologic functions after trauma/ hemorrhage, and so their use in the clinical arena also appears to be warranted [172-174]. 


\section{Conclusion}

Hemorrhagic shock is a leading cause of death in trauma patients worldwide. Despite improved resuscitation strategies for severely injured patients who present in shock, these transfusions are associated with development of MOF, increased ICU admissions and length of stay, increased hospital length of stay, and increased mortality. An important contributing factor may be the marked suppression of cellmediated immunity after hemorrhage treated with adequate fluid resuscitation, which is associated with an increased susceptibility to subsequent sepsis. Other factors that may profoundly influence outcomes after hemorrhage include age, sex, nutritional status, socioeconomic background, and preexisting disease or infection.

Bleeding control, maintenance of tissue oxygenation with fluid resuscitation, coagulation support, and maintaining normothermia remain mainstays of therapy for patients with hemorrhagic shock. However, further benefits are anticipated from new technologies that are being brought into clinical use, especially hypertonic colloid saline, HBOCs, recombinant factor VIla, and less invasive early monitors. In addition, promising results from experimental studies have demonstrated that recombinant HSA as a plasma expander as well as administration of vasopressin, adrenomedullin, estradiol, metoclopramide, prolactin, flutamide, or DHEA to maintain cardiac output, tissue perfusion and oxygenation may be beneficial in hemorrhagic shock. Furthermore, prevention of capillary leakage due to blockade of reactive oxygen formation, maintenance of endothelial barrier function, and attenuation of the hyperinflammatory immunological response are additional experimental approaches that are of therapeutic interest in combating hemorrhage-associated complications.

Hemorrhagic shock can be rapidly fatal. It is self-evident that prevention of injury is preferable and feasible, but control of hemorrhage in the earliest phases of care, recognition and monitoring of individual risk factors, and therapeutic modulation of the inflammatory immune response may represent the next generation of care in hemorrhagic shock. Further randomized controlled clinical trials are needed, but existing ethical requirements must be maintained and standardized criteria for enrolling comparable patient populations must be utilized.

\section{Competing interests}

The authors declare that they have no competing interests.

\section{Acknowledgements}

The authors wish to express their sincere thanks to Bobbi Smith for her superb help in editing this manuscript. This work was supported by USPHS grants R37 GM39519 and RO1 GM37127.

\section{References}

1. Kauvar DS, Lefering R, Wade CE: Impact of hemorrhage on trauma outcome: an overview of epidemiology, clinical presentations, and therapeutic considerations. J Trauma 2006, 60:S3-S11.
2. Kauvar DS, Wade CE: The epidemiology and modern management of traumatic hemorrhage: US and international perspectives. Crit Care 2005, 9:S1-S9.

3. Rossaint R, Cerny V, Coats TJ, Duranteau J, Fernandez-Mondejar E, Gordini G, Stahel PF, Hunt BJ, Neugebauer E, Spahn DR: Key issues in advanced bleeding care in trauma. Shock 2006, 26: 322-331.

4. Durham RM, Moran JJ, Mazuski JE, Shapiro MJ, Baue AE, Flint LM: Multiple organ failure in trauma patients. J Trauma 2003, 55:608-616.

5. Franklin GA, Boaz PW, Spain DA, Lukan JK, Carrillo EH, Richardson JD: Prehospital hypotension as a valid indicator of trauma team activation. J Trauma 2000, 48:1034-1037.

6. Heckbert SR, Vedder NB, Hoffman W, Winn RK, Hudson LD Jurkovich GJ, Copass MK, Harlan JM, Rice CL, Maier RV: Outcome after hemorrhagic shock in trauma patients. $j$ Trauma 1998, 45:545-549.

7. Peitzman AB, Billiar TR, Harbrecht BG, Kelly E, Udekwu AO, Simmons RL: Hemorrhagic shock. Curr Probl Surg 1995, 32: 925-1002.

8. Cairns CB: Rude unhinging of the machinery of life: metabolic approaches to hemorrhagic shock. Curr Opin Crit Care 2001, 7:437-443.

9. Jarrar D, Chaudry IH, Wang P: Organ dysfunction following hemorrhage and sepsis: mechanisms and therapeutic approaches [review]. Int J Mol Med 1999, 4:575-583.

10. Ayala $A$, Ertel $W$, Chaudry $\mathrm{IH}$ : Trauma-induced suppression of antigen presentation and expression of major histocompatibility class II antigen complex in leukocytes. Shock 1996, 5: 79-90.

11. Chaudry $\mathrm{IH}$, Zellweger $\mathrm{R}$, Ayala A: The role of bacterial translocation on Kupffer cell immune function following hemorrhage. Prog Clin Biol Res 1995, 392:209-218.

12. Harbrecht BG, Billiar TR: The role of nitric oxide in Kupffer cellhepatocyte interactions. Shock 1995, 3:79-87.

13. Szabó C, Billiar TR: Novel roles of nitric oxide in hemorrhagic shock. Shock 1999, 12:1-9.

14. Hierholzer C, Billiar TR: Molecular mechanisms in the early phase of hemorrhagic shock. Langenbecks Arch Surg 2001, 386:302-308.

15. West MA, Shapiro MB, Nathens AB, Johnson JL, Moore EE, Minei JP, Bankey PE, Freeman B, Harbrecht BG, McKinley BA, Moore FA, Maier RV: Inflammation and the host response to injury, a large-scale collaborative project: patient-oriented research core-standard operating procedures for clinical care. IV. Guidelines for transfusion in the trauma patient. $J$ Trauma 2006, 61:436-439.

16. Moore FA, McKinley BA, Moore EE, Nathens AB, West M, Shapiro MB, Bankey P, Freeman B, Harbrecht BG, Johnson JL, Minei JP, Maier RV: Inflammation and the host response to injury, a large-scale collaborative project: patient-oriented research core: standard operating procedures for clinical care. III. Guidelines for shock resuscitation. J Trauma 2006, 61:82-89.

17. Spahn DR, Cerny V, Coats TJ, Duranteau J, Fernandez-Mondejar E, Gordini G, Stahel PF, Hunt BJ, Komadina R, Neugebauer E, Ozier Y, Riddez L, Schultz A, Vincent JL, Rossaint R; Task Force for Advanced Bleeding Care in Trauma: Management of bleeding following major trauma: a European guideline. Crit Care 2007, 11:R17.

18. Malone DL, Dunne J, Tracy JK, Putnam AT, Scalea TM, Napolitano LM: Blood transfusion, independent of shock severity, is associated with worse outcome in trauma. J Trauma 2003, 54: 898-905.

19. Eastridge BJ, Malone D, Holcomb JB: Early predictors of transfusion and mortality after injury: a review of the data-based literature. J Trauma 2006, 60:S20-S25.

20. Napolitano L: Cumulative risks of early red blood cell transfusion. J Trauma 2006, 60:S26-S34.

21. Cotton BA, Guy JS, Morris JA Jr, Abumrad NN: The cellular, metabolic, and systemic consequences of aggressive fluid resuscitation strategies. Shock 2006, 26:115-121.

22. Choudhry MA, Bland $\mathrm{KI}$, Chaudry IH: Trauma and immune response: effect of gender differences. Injury 2007, 38:1382-1391.

23. Bone RC: Toward an epidemiology and natural history of SIRS (systemic inflammatory response syndrome). JAMA 1992, 268:3452-3455. 
24. Center for Disease Control: Mortality patterns: United States, 1989. MMWR Morb Mortal Wkly Rep 1992, 41:121-125

25. McGowan JE, Barnes MW, Finland N: Bacteremia at Boston City Hospital: occurrence and mortality during 12 selected years (1935-1972) with special reference to hospital-acquired cases. J Infect Dis 1975, 132:316-335.

26. Schroder J, Kahlke V, Staubach KH, Zabel P, Stuber F: Gender differences in human sepsis. Arch Surg 1998, 133:1200-1205.

27. Angele MK, Schwacha MG, Ayala A: Effect of gender and sex hormones on immune responses following shock. Shock 2000, 14:81-90.

28. Angele MK, Knöferl MW, Ayala A, Cioffi WG, Bland KI, Chaudry $\mathrm{IH}$ : Male and female sex steroids: do they produce deleterious or beneficial effects on immune responses following trauma-hemorrhage? Surg Forum 1998, 49:43-45.

29. Knoferl MW, Diodato MD, Angele MK, Ayala A, Cioffi WG, Bland $\mathrm{KI}$, Chaudry IH: Do female sex steroids adversely or beneficially affect the depressed immune responses in males after trauma-hemorrhage? Arch Surg 2000, 135:425-433.

30. Deitch EA, Livingston DH, Lavery RF: Hormonally active women tolerate shock-trauma better than do men: a prospective study of over 4000 trauma patients. Ann Surg 2007, 246:447453.

31. Catania RA, Angele MK, Ayala A, Cioffi WG, Bland KI, Chaudry $\mathrm{IH}$ : Dehydroepiandrosterone (DHEA) restores immune function following trauma-hemorrhage by a direct effect on T-lymphocytes. Cytokine 1998, 11:443-450.

32. Angele MK, Catania RA, Ayala A, Cioffi WG, Bland KI, Chaudry $\mathrm{IH}$ : Dehydroepiandrosterone (DHEA): an inexpensive steroid hormone which decreases the mortality from sepsis. Arch Surg 1998, 133:1281-1288.

33. Frantz MC, Prix NJ, Wichmann MW, van den Engel NK, Hernandez-Richter T, Faist E, Chaudry IH, Jauch KW, Angele MK: Dehydroepiandrosterone restores depressed peripheral blood mononuclear cell function following major abdominal surgery via the estrogen receptors. Crit Care Med 2005, 33:17791786.

34. Schneider CP, Schwacha MG, Chaudry IH: Influence of gender and age on T-cell responses in a murine model of traumahemorrhage: differences between circulating and tissue-fixed cells. J Appl Physio/ 2006, 100:826-833.

35. Schneider CP, Schwacha MG, Chaudry IH: Impact of sex and age on bone marrow immune responses in a murine model of trauma-hemorrhage. J Appl Physio/ 2007, 102:113-121.

36. Hildebrand F, Pape HC, van GM, Meier S, Hasenkamp S, Krettek C, Stuhrmann M: Genetic predisposition for a compromised immune system after multiple trauma. Shock 2005, 24:518522.

37. Giannoudis PV, van GM, Tsiridis E, Pape HC: The genetic predisposition to adverse outcome after trauma. J Bone Joint Surg $\mathrm{Br}$ 2007, 89:1273-1279.

38. Schroeder O, Schulte KM, Schroeder J, Ekkernkamp A, Laun RA: The -1082 interleukin-10 polymorphism is associated with acute respiratory failure after major trauma: a prospective cohort study. Surgery 2008, 143:233-242.

39. Canter JA, Norris PR, Moore JH, Jenkins JM, Morris JA: Specific polymorphic variation in the mitochondrial genome and increased in-hospital mortality after severe trauma. Ann Surg 2007, 246:406-411.

40. Catania RA, Chaudry IH: Immunological consequences of trauma and shock. Ann Acad Med Singapore 1999, 28:120132.

41. Moore FA, McKinley BA, Moore EE: The next generation in shock resuscitation. Lancet 2004, 363:1988-1996.

42. Revell M, Greaves I, Porter K: Endpoints for fluid resuscitation in hemorrhagic shock. J Trauma 2003, 54:S63-S67.

43. Rixen D, Siegel JH: Bench-to-bedside review: oxygen debt and its metabolic correlates as quantifiers of the severity of hemorrhagic and post-traumatic shock. Crit Care 2005, 9:441453.

44. Rixen D, Raum M, Holzgraefe B, Schafer U, Hess S, Tenhunen J, Tuomisto L, Neugebauer EA; Shock and Trauma Study Group: Local lactate and histamine changes in small bowel circulation measured by microdialysis in pig hemorrhagic shock. Shock 2002, 18:355-359.

45. Beerthuizen GIJM, Goris RJA, Kreuzer FJA: Early detection of shock in critically ill patients by skeletal muscle $\mathrm{PO}_{2}$ assess- ment. Arch Surg 1989, 124:853-855.

46. Hopf HW, Glass-Heidenreich L, Silva J, Pearce F, Ochsner MG Rozycki G, et al:: Subcutaneous tissue oxygen tension in 'well resuscitated' trauma patients. Crit Care Med 1994, 22:A60.

47. McKinley BA, Parmley CL, Butler BD: Skeletal muscle $\mathbf{P O}_{2}$, $\mathrm{PCO}_{2}$, and $\mathrm{pH}$ in hemorrhage, shock, and resuscitation in dogs. J Trauma 1997, 44:119-127.

48. Knudson MM, Lee S, Erickson V, Morabito D, Derugin N, Manley GT: Tissue oxygen monitoring during hemorrhagic shock and resuscitation: a comparison of lactated Ringer's solution, hypertonic saline dextran, and HBOC-201. J Trauma 2003, 54: 242-252.

49. Cairns CB, Moore FA, Haenel JB: Evidence for early supply independent mitochondrial dysfunction in patients developing multiple organ failure after trauma. J Trauma 1997, 42: 532-536.

50. Clavijo-Alvarez JA, Sims CA, Menconi M, Shim I, Ochoa C, Puyana JC: Bladder mucosa $\mathrm{pH}$ and $\mathrm{Pco} 2$ as a minimally invasive monitor of hemorrhagic shock and resuscitation. $J$ Trauma 2004, 57:1199-1209.

51. Clavijo-Alvarez JA, Sims CA, Pinsky MR, Puyana JC: Monitoring skeletal muscle and subcutaneous tissue acid-base status and oxygenation during hemorrhagic shock and resuscitation. Shock 2005, 24:270-275.

52. Velmahos GC, Demetriades D, Shoemaker WC, Chan LS, Tat evossian R, Wo CC, Vassiliu P, Cornwell EE 3rd, Murray JA, Roth $B$, Belzberg $H$, Asensio JA, Berne TV: Endpoints of resuscitation of critically injured patients: normal or supranormal? A prospective randomized trial. Ann Surg 2000, 232:409-418.

53. Ristagno G, Tang W, Sun S, Weil MH: Role of buccal PCO2 in the management of fluid resuscitation during hemorrhagic shock. Crit Care Med 2006, 34:S442-S446.

54. Vaezy S, Zderic V: Hemorrhage control using high intensity focused ultrasound. Int J Hyperthermia 2007, 23:203-211.

55. Chaudry IH, Ayala A: Immunological Aspects of Hemorrhage. Austin, TX: Medical Intelligence Unit, R.G. Landes Company; 1992.

56. Ayala A, Perrin MM, Meldrum DR, Ertel W, Chaudry IH: Hemorrhage induces an increase in serum TNF which is not associated with elevated levels of endotoxin. Cytokine 1990, 2: 170-174.

57. Ayala A, Wang P, Ba ZF, Perrin MM, Ertel W, Chaudry IH: Differential alterations in plasma IL- 6 and TNF levels following trauma and hemorrhage. Am J Physiol 1991, 260:R167-R171.

58. Roumen RM, Hendriks T, van der Ven-Jongekrijg J, Nieuwenhuijzen GA, Sauerwein RW, van der Meer JW, Goris RJ: Cytokine patterns in patients after major surgery, hemorrhagic shock, and severe blunt trauma. Ann Surg 1993, 6:769-776.

59. Romagnani S: Th1 and Th2 in human diseases. Clin Immunol Immunopathol 1996, 80:225-235.

60. Martin C, Boisson C, Haccoun M, Thomachot L, Mege JL: Patterns of cytokine evolution (tumor necrosis factor- $\alpha$ and interleukin-6) after septic shock, hemorrhagic shock, and severe trauma. Crit Care Med 1997, 25:1813-1819.

61. Angele MK, Chaudry IH: Surgical trauma and immunosuppression: pathophysiology and potential immunomodulatory approaches. Langenbecks Arch Surg 2005, 390:333-341.

62. Menger MD, Vollmar B: Surgical trauma: hyperinflammation versus immunosuppression? Langenbecks Arch Surg 2004, 389:475-484.

63. Zedler S, Faist E: The impact of endogenous triggers on trauma-associated inflammation. Curr Opin Crit Care 2006, 12:595-601

64. Cobb JP, O'Keefe GE: Injury research in the genomic era. Lancet 2004, 363:2076-2083.

65. Tschoeke SK, Ertel W: Immunoparalysis after multiple trauma. Injury 2007, 38:1346-1357.

66. Shires T, Coln D, Carrico J, Lightfoot S: Fluid therapy in hemorrhagic shock. Arch Surg 1964, 88:688-693.

67. Healey MA, Davis RE, Liu FC, Loomis WH, Hoyt DB: Lactated ringer's is superior to normal saline in a model of massive hemorrhage and resuscitation. J Trauma 1998, 45:894-899.

68. Todd SR, Malinoski D, Muller PJ, Schreiber MA: Lactated Ringer's is superior to normal saline in the resuscitation of uncontrolled hemorrhagic shock. J Trauma 2007, 62:636-639.

69. Savage SA, Fitzpatrick CM, Kashyap VS, Clouse WD, Kerby JD: Endothelial dysfunction after lactated Ringer's solution resus- 
citation for hemorrhagic shock. J Trauma 2005, 59:284-290

70. Sims CA, Wattanasirichaigoon S, Menconi MJ, Ajami AM, Fink MP: Ringer's ethyl pyruvate solution ameliorates ischemia/ reperfusion-induced intestinal mucosal injury in rats. Crit Care Med 2001, 29:1513-1518.

71. Mulier KE, Beilman GJ, Conroy MJ, Taylor JH, Skarda DE, Hammer BE: Ringer's ethyl pyruvate in hemorrhagic shock and resuscitation does not improve early hemodynamics or tissue energetics. Shock 2005, 23:248-252.

72. Holcroft JW, Trunkey DD: Extravascular lung water following hemorrhagic shock in the baboon: comparison between resuscitation with Ringer's lactate and Plasmanate. Ann Surg 1974, 180:408-417.

73. Schierhout G, Roberts I: Fluid resuscitation with colloid or crystalloid solutions in critically ill patients: a systematic review of randomised trials. BMJ 1998, 316:961-964.

74. Choi PT, Yip G, Quinonez LG, Cook DJ: Crystalloids vs. colloids in fluid resuscitation: a systematic review. Crit Care Med 1999, 27:200-210.

75. Rizoli SB: Crystalloids and colloids in trauma resuscitation: a brief overview of the current debate. J Trauma 2003, 54:S82S88.

76. Watters JM, Tieu BH, Todd SR, Jackson T, Muller PJ, Malinoski D, Schreiber MA: Fluid resuscitation increases inflammatory gene transcription after traumatic injury. J Trauma 2006, 61: 300-308.

77. Roberts I, Alderson P, Bunn F: Colloids versus crystalloids for fluid resuscitation in critically ill patients. Cochrane Database Syst Rev 2004:CD000567.

78. Vercueil A, Grocott MP, Mythen MG: Physiology, pharmacology, and rationale for colloid administration for the maintenance of effective hemodynamic stability in critically ill patients. Transfus Med Rev 2005, 19:93-109.

79. Lee CC, Chang IJ, Yen ZS: Effect of different resuscitation fluids on cytokine response in a rat model of hemorrhagic shock. Shock 2005, 24:177-181.

80. Cochrane Injuries Group: Human albumin administration in critically ill patients: systematic review of randomised controlled trials. Cochrane Injuries Group Albumin Reviewers. BMJ 1998, 317:235-240.

81. Matsushita S, Chuang VT, Kanazawa M, Tanase S, Kawai K, Maruyama T, Suenaga A, Otagiri M: Recombinant human serum albumin dimer has high blood circulation activity and low vascular permeability in comparison with native human serum albumin. Pharm Res 2006, 23:882-891.

82. Finfer S, Bellomo R, Boyce N, French J, Myburgh J, Norton R: A comparison of albumin and saline for fluid resuscitation in the intensive care unit. N Engl J Med 2004, 350:2247-2256.

83. de Felippe J, Jr, Timoner J, Velasco IT, Lopes OU, Rocha-e-Silva $\mathrm{M}$ : Treatment of refractory hypovolaemic shock by $7.5 \%$ sodium chloride injections. Lancet 1980, 2:1002-1004.

84. Bagshaw SM, Bellomo R: The influence of volume management on outcome. Curr Opin Crit Care 2007, 13:541-548.

85. Nascimento P, Jr., de Paiva FO, de Carvalho LR, Braz JR: Early hemodynamic and renal effects of hemorrhagic shock resuscitation with lactated Ringer's solution, hydroxyethyl starch, and hypertonic saline with or without $6 \%$ dextran-70. J Surg Res 2006, 136:98-105.

86. Smith GJ, Kramer GC, Perron P, Nakayama S, Gunther RA, Holcroft JW: A comparison of several hypertonic solutions for resuscitation of bled sheep. J Surg Res 1985, 39:517-528

87. Wade CE, Kramer GC, Grady JJ, Fabian TC, Younes RN: Efficacy of hypertonic $7.5 \%$ saline and $6 \%$ dextran-70 in treating trauma: a meta-analysis of controlled clinical studies. Surgery 1997, 122:609-616.

88. Himmelseher S: Hypertonic saline solutions for treatment of intracranial hypertension. Curr Opin Anaesthesiol 2007, 20: 414-426.

89. Cooper DJ, Myles PS, McDermott FT, Murray LJ, Laidlaw J, Cooper G, Tremayne AB, Bernard SS, Ponsford J; HTS Study Investigators: Prehospital hypertonic saline resuscitation of patients with hypotension and severe traumatic brain injury: a randomized controlled trial. JAMA 2004, 291:1350-1357.

90. Kentner R, Safar P, Prueckner S, Behringer W, Wu X, Henchir J, Ruemelin A, Tisherman SA: Titrated hypertonic/hyperoncotic solution for hypotensive fluid resuscitation during uncontrolled hemorrhagic shock in rats. Resuscitation 2005, 65:87-95.
91. Watters JM, Tieu BH, Differding JA, Muller PJ, Schreiber MA: A single bolus of $3 \%$ hypertonic saline with $6 \%$ dextran provides optimal initial resuscitation after uncontrolled hemorrhagic shock. J Trauma 2006, 61:75-81.

92. Coimbra R, Melbostad H, Hoyt DB: Effects of phosphodiesterase inhibition on the inflammatory response after shock: role of pentoxifylline. J Trauma 2004, 56:442-449.

93. Yada-Langui MM, Coimbra R, Lancellotti C, Mimica I, Garcia C, Correia N, Jr, Rocha e Silva M: Hypertonic saline and pentoxifylline prevent lung injury and bacterial translocation after hemorrhagic shock. Shock 2000, 14:594-598.

94. Coimbra R, Porcides R, Loomis W, Melbostad H, Lall R, Deree J, Wolf $P$, Hoyt DB: HSPTX protects against hemorrhagic shock resuscitation-induced tissue injury: an attractive alternative to Ringer's lactate. J Trauma 2006, 60:41-51.

95. Deree J, de CT, Shenvi E, Loomis WH, Hoyt DB, Coimbra R: Hypertonic saline and pentoxifylline attenuates gut injury after hemorrhagic shock: the kinder, gentler resuscitation. $J$ Trauma 2007, 62:818-827.

96. Brasel KJ, Bulger E, Cook AJ, Morrison LJ, Newgard CD, Tisherman SA, Kerby JD, Coimbra R, Hata JS, Hoyt DB; Resuscitation Outcomes Consortium Investigators: Hypertonic resuscitation: design and implementation of a prehospital intervention trial. $J$ Am Coll Surg 2008, 206:220-232.

97. Moore FA, Moore EE, Sauaia A: Blood transfusion. An independent risk factor for postinjury multiple organ failure. Arch Surg 1997, 132:620-624.

98. Gong MN, Thompson BT, Williams P, Pothier L, Boyce PD, Christiani DC: Clinical predictors of and mortality in acute respiratory distress syndrome: potential role of red cell transfusion. Crit Care Med 2005, 33:1191-1198.

99. Shorr AF, Jackson WL, Kelly KM, Fu M, Kollef MH: Transfusion practice and blood stream infections in critically ill patients. Chest 2005, 127:1722-1728.

100. Klein HG, Spahn DR, Carson JL: Red blood cell transfusion in clinical practice. Lancet 2007, 370:415-426.

101. Spahn DR, Kocian R: Artificial $\mathrm{O}_{2}$ carriers: status in 2005. Curr Pharm Des 2005, 11:4099-4114.

102. Riess JG: Understanding the fundamentals of perfluorocarbons and perfluorocarbon emulsions relevant to in vivo oxygen delivery. Artif Cells Blood Substit Immobil Biotechnol 2005, 33:47-63.

103. Habler OP, Kleen MS, Hutter JW, Podtschaske AH, Tiede M, Kemming Gl, Welte MV, Corso CO, Batra S, Keipert PE, Faithfull NS, Messmer KF: Hemodilution and intravenous perflubron emulsion as an alternative to blood transfusion: effects on tissue oxygenation during profound hemodilution in anesthetized dogs. Transfusion 1998, 38:145-155.

104. Habler O, Kleen M, Hutter J, Podtschaske A, Tiede M, Kemming G, Welte M, Corso C, Batra S, Keipert P, Faithfull S, Messmer K: IV perflubron emulsion versus autologous transfusion in severe normovolemic anemia: effects on left ventricular perfusion and function. Res Exp Med (Berl) 1998, 197:301-318.

105. Spahn DR, van Brempt R, Theilmeier G, Reibold JP, Welte M, Heinzerling $\mathrm{H}$, Birck KM, Keipert PE, Messmer K, Heinzerling $\mathrm{H}$, Birck KM, Keipert PE, Messmer K: Perflubron emulsion delays blood transfusions in orthopedic surgery. European Perflubron Emulsion Study Group. Anesthesiology 1999, 91:11951208.

106. Frumento RJ, Mongero L, Naka Y, nett-Guerrero E: Preserved gastric tonometric variables in cardiac surgical patients administered intravenous perflubron emulsion. Anesth Analg 2002, 94:809-814.

107. Spahn DR, Waschke KF, Standl T, Motsch J, Van HL, Welte M, Gombotz H, Coriat P, Verkh L, Faithfull S, Kepert P; Eurpoean Perflubron Emulsion in Non-Cardiac Surgery Study Group: Use of perflubron emulsion to decrease allogeneic blood transfusion in high-blood-loss non-cardiac surgery: results of a European phase 3 study. Anesthesiology 2002, 97:1338-1349.

108. Habler O, Kleen M, Pape A, Meisner F, Kemming G, Messmer K: Diaspirin-crosslinked hemoglobin reduces mortality of severe hemorrhagic shock in pigs with critical coronary stenosis. Crit Care Med 2000, 28:1889-1898.

109. Nolte D, Steinhauser P, Pickelmann S, Berger S, Hartl R, Messmer $\mathrm{K}$ : Effects of diaspirin-cross-linked hemoglobin (DCLHb) on local tissue oxygen tension in striated skin muscle: an efficacy study in the hamster. J Lab Clin Med 1997, 130:328-338. 
110. Schultz SC, Hamilton IN Jr, Malcolm DS: Use of base deficit to compare resuscitation with lactated Ringer's solution, Haemaccel, whole blood, and diaspirin cross-linked hemoglobin following hemorrhage in rats. J Trauma 1993, 35:619-625.

111. Sprung J, Mackenzie CF, Barnas GM, Williams JE, Parr M, Christenson RH, Hoff GH, Sakamoto R, Kramer A, Lottes M: Oxygen transport and cardiovascular effects of resuscitation from severe hemorrhagic shock using hemoglobin solutions. Crit Care Med 1995, 23:1540-1553.

112. Johnson JL, Moore EE, Gonzalez RJ, Fedel N, Partrick DA, Silliman CC: Alteration of the postinjury hyperinflammatory response by means of resuscitation with a red cell substitute. J Trauma 2003, 54:133-139.

113. Pickelmann S, Nolte D, Leiderer R, Schutze E, Messmer K: Attenuation of postischemic reperfusion injury in striated skin muscle by diaspirin-cross-linked Hb. Am J Physiol 1998, 275:H361-H368

114. Botzlar A, Nolte D, Messmer K: Effects of ultra-purified polymerized bovine hemoglobin on the microcirculation of striated skin muscle in the hamster. Eur J Med Res 1996, 1: 471-478.

115. Sloan EP, Koenigsberg M, Gens D, Cipolle M, Runge J, Mallory MN, Rodman G Jr: Diaspirin cross-linked hemoglobin (DCLHb) in the treatment of severe traumatic hemorrhagic shock: a randomized controlled efficacy trial. JAMA 1999, 282:18571864.

116. Gould SA, Moore EE, Hoyt DB, Ness PM, Norris EJ, Carson JL, Hides GA, Freeman IH, DeWoskin R, Moss GS: The life-sustaining capacity of human polymerized hemoglobin when red cells might be unavailable. J Am Coll Surg 2002, 195:445-452.

117. Alayash Al: Hemoglobin-based blood substitutes: oxygen carriers, pressor agents, or oxidants? Nat Biotechnol 1999, 17: 545-549.

118. Fitzpatrick CM, Biggs KL, Atkins BZ, Quance-Fitch FJ, Dixon PS, Savage SA, Jenkins DH, Kerby JD: Prolonged low-volume resuscitation with HBOC-201 in a large-animal survival model of controlled hemorrhage. J Trauma 2005, 59:273-281.

119. Arnaud F, Hammett M, Asher L, Philbin N, Rice J, Dong F, Pearce B, Flournoy WS, Nicholson C, McCarron R, Freilich D: Effects of bovine polymerized hemoglobin on coagulation in controlled hemorrhagic shock in swine. Shock 2005, 24:145-152.

120. Rice J, Philbin N, Handrigan M, Hall C, McGwin G, Ahlers S, Pearce LB, Arnaud F, McCarron R, Freilich D: Vasoactivity of bovine polymerized hemoglobin (HBOC-201) in swine with traumatic hemorrhagic shock with and without brain injury. $J$ Trauma 2006, 61:1085-1099.

121. Wettstein R, Tsai AG, Erni D, Winslow RM, Intaglietta M: Resuscitation with polyethylene glycol-modified human hemoglobin improves microcirculatory blood flow and tissue oxygenation after hemorrhagic shock in awake hamsters. Crit Care Med 2003, 31:1824-1830

122. Winslow RM: Current status of oxygen carriers ('blood substitutes'): 2006. Vox Sang 2006, 91:102-110.

123. Goto Y, Terajima K, Tsueshita T, Miyashita M, Horinouchi H, Sakai $H$, Tsuchida E, Sakamoto A: Fluid resuscitation with hemoglobin-vesicle solution does not increase hypoxia or inflammatory responses in moderate hemorrhagic shock. Biomed Res 2006, 27:283-288.

124. Terajima K, Tsueshita T, Sakamoto A, Ogawa R: Fluid resuscitation with hemoglobin vesicles in a rabbit model of acute hemorrhagic shock. Shock 2006, 25:184-189.

125. Voelckel WG, Wenzel V: Managing hemorrhagic shock: fluids on the way out: drugs on the way in? Crit Care Med 2003, 31: 2552-2553.

126. Chaudry IH, Baue AE: Overview of hemorrhagic shock. In Pathophysiology of Shock, Anoxia, and Ischemia. Edited by Cowley RA, Trump BF. Baltimore: Williams and Wilkins; 1982:203-219

127. Daut J, Maier-Rudolph W, von BN, Mehrke G, Gunther K, GoedelMeinen L: Hypoxic dilation of coronary arteries is mediated by ATP-sensitive potassium channels. Science 1990, 247:13411344.

128. Rushing GD, Britt RC, Collins JN, Cole FJ, Weireter LJ, Britt LD: Adrenal insufficiency in hemorrhagic shock. Am Surg 2006, 72:552-554.

129. Holmes CL, Landry DW, Granton JT: Science review: vasopressin and the cardiovascular system part 1 - receptor phys- iology. Crit Care 2003, 7:427-434.

130. Wenzel V, Krismer AC, Arntz HR, Sitter H, Stadlbauer $\mathrm{KH}$ Lindner $\mathrm{KH}$ : A comparison of vasopressin and epinephrine for out-of-hospital cardiopulmonary resuscitation. N Engl J Med 2004, 350:105-113.

131. Dunser MW, Mayr AJ, Ulmer H, Knotzer H, Sumann G, Pajk W, et al.: Arginine vasopressin in advanced vasodilatory shock: a prospective, randomized, controlled study. Circulation 2003, 107:2313-2319.

132. Voelckel WG, Raedler C, Wenzel V, Lindner KH, Krismer AC, Schmittinger CA, Herff H, Rheinberger K, Königsrainer A: Arginine vasopressin, but not epinephrine, improves survival in uncontrolled hemorrhagic shock after liver trauma in pigs. Crit Care Med 2003, 31:1160-1165.

133. Feinstein AJ, Cohn SM, King DR, Sanui M, Proctor KG: Early vasopressin improves short-term survival after pulmonary contusion. J Trauma 2005, 59:876-882

134. Sanui M, King DR, Feinstein AJ, Varon AJ, Cohn SM, Proctor KG: Effects of arginine vasopressin during resuscitation from hemorrhagic hypotension after traumatic brain injury. Crit Care Med 2006, 34:433-438.

135. Lienhart HG, Wenzel V, Braun J, Dorges V, Dunser M, Gries A Hasibeder WR, Helm M, Lefering R, Schlechtriemen T, Trimmel $\mathrm{H}$, Ulmer H, Ummenhofer W, Voelckel WG, Waydhas C, Lindner $\mathrm{K}$ : Vasopressin for therapy of persistent traumatic hemorrhagic shock: the VITRIS.at study. Anaesthesist 2007, 56:145148.

136. Sperry JL, Minei JP, Frankel HL, West MA, Harbrecht BG, Moore $\mathrm{EE}$, Maier RV, Nirula R: Early use of vasopressors after injury: caution before constriction. J Trauma 2008, 64:9-14.

137. Wu R, Wang P: Preclinical studies with adrenomedullin and its binding protein as cardiovascular protective agents for hemorrhagic shock. Cardiovasc Drug Rev 2006, 24:204-213.

138. Song GY, Chung CS, Schwacha MG, Jarrar D, Chaudry IH, Ayala A: Splenic immune suppression in sepsis: A role for IL-10induced changes in P38 MAPK signaling. J Surg Res 1999, 83: 36-43.

139. Yang S, Zhou M, Chaudry IH, Wang P: Novel approach to prevent the transition from the hyperdynamic phase to the hypodynamic phase of sepsis: role of adrenomedullin and adrenomedullin binding protein-1. Ann Surg 2002, 236:625-633.

140. Wu R, Dong W, Zhou M, Simms HH, Marini CP, Ravikumar TS, Wang P: Adrenomedullin and adrenomedullin binding protein-1 prevent metabolic acidosis after uncontrolled hemorrhage in rats. Crit Care Med 2007, 35:912-918.

141. Garrioch MA: The body's response to blood loss. Vox Sang 2004, 87:74-76.

142. Cosgriff N, Moore EE, Sauaia A, Kenny-Moynihan M, Burch JM, Galloway B: Predicting life-threatening coagulopathy in the massively transfused trauma patient: hypothermia and acidosis revisited. J Trauma 1997, 42:857-861.

143. Erber WN, Perry DJ: Plasma and plasma products in the treatment of massive haemorrhage. Best Pract Res Clin Haematol 2006, 19:97-112.

144. Goodnough LT, Shander AS: Recombinant factor VIla: safety and efficacy. Curr Opin Hematol 2007, 14:504-509.

145. Schreiber MA, Holcomb JB, Hedner U, Brundage SI, Macaitis JM, Hoots K: The effect of recombinant factor VIla on coagulopathic pigs with grade V liver injuries. J Trauma 2002, 53:252257.

146. Martinowitz U, Holcomb JB, Pusateri AE, Stein M, Onaca N, Freidman M, Macaitis JM, Castel D, Hedner U, Hess JR: Intravenous rFVIla administered for hemorrhage control in hypothermic coagulopathic swine with grade $\mathbf{V}$ liver injuries. J Trauma 2001, 50:721-729.

147. Spinella PC, Perkins JG, McLaughlin DF, Niles SE, Grathwohl KW, Beekley AC, Salinas J, Mehta S, Wade CE, Holcomb JB: The effect of recombinant activated factor VII on mortality in combat-related casualties with severe trauma and massive transfusion. J Trauma 2008, 64:286-293.

148. Boffard K, Riou B, Warren B, Choong PI, Rizoli S, Rossaint R, Axelsen M, Kluger Y; NovoSeven Trauma Study Group: Recombinant factor VIla as adjunctive therapy for bleeding control in severely injured trauma patients: two parallel randomized, placebo-controlled, double-blind clinical trials. J Trauma 2005, 59:8-15.

149. Stanworth SJ, Birchall J, Doree CJ, Hyde C: Recombinant factor 
VIla for the prevention and treatment of bleeding in patients without haemophilia. Cochrane Database Syst Rev 2007: CD005011.

150. Vincent JL, Rossaint R, Riou B, Ozier Y, Zideman D, Spahn DR: Recommendations on the use of recombinant activated factor VII as an adjunctive treatment for massive bleeding: a European perspective. Crit Care 2006, 10:R120.

151. Wang $H$, Bloom $O$, Zhang $M$, Vishnubhakat $J M$, Ombrellino $M$, Che J, Frazier A, Yang H, Ivanova S, Borovikova L, Manogue KR, Faist E, Abraham E, Andersson J, Andersson U, Molina PE, Abumrad NN, Sama A, Tracey KJ: HMG-1 as a late mediator of endotoxin lethality in mice. Science 1999, 285:248-251.

152. Yang $H$, Ochani M, Li J: Reversing established sepsis with antagonists of endogenous high-mobility group box 1 . Proc Natl Acad Sci USA 2004, 101:296-301.

153. Andersson U, Wang H, Palmblad K, Aveberger AC, Bloom O, Erlandsson-Harris $\mathrm{H}$, Janson A, Kokkola R, Zhang $\mathrm{M}$, Yang $\mathrm{H}$, Tracey KJ: High mobility group 1 protein $(\mathrm{HMG}-1)$ stimulates proinflammatory cytokine synthesis in human monocytes. $J$ Exp Med 2000, 192:565-570.

154. Rendon-Mitchell B, Ochani M, Li J, Han J, Wang $H$, Yang $H$, Susarla S, Czura C, Mitchell RA, Chen G, Sama AE, Tracey KJ, Wang $\mathrm{H}$ : IFN-gamma induces high mobility group box 1 protein release partly through a TNF-dependent mechanism. $J$ Immunol 2003, 170:3890-3897.

155. Yang R, Harada T, Mollen KP, Prince JM, Levy RM, Englert JA, Gallowitsch-Puerta M, Yang L, Yang H, Tracey KJ, Harbrecht BG, Billiar TR, Fink MP: Anti-HMGB1 neutralizing antibody ameliorates gut barrier dysfunction and improves survival after hemorrhagic shock. Mol Med 2006, 12:105-114.

156. Sorensson J, Matejka GL, Ohlson M, Haraldsson B: Human endothelial cells produce orosomucoid, an important component of the capillary barrier. Am J Physiol 1999, 276:H530H534.

157. Vasson MP, Roch-Arveiller M, Couderc R, Baguet JC, Raichvarg D: Effects of alpha-1 acid glycoprotein on human polymorphonuclear neutrophils: influence of glycan microheterogeneity. Clin Chim Acta 1994, 224:65-71.

158. Kuebler JF, Toth B, Yokoyama Y, Bland KI, Rue LW, III, Chaudry $\mathrm{IH}$ : Alpha1-acid-glycoprotein protects against trauma-hemorrhagic shock. J Surg Res 2004, 119:21-28.

159. Mok YY, Atan MS, Yoke PC, Zhong JW, Bhatia M, Moochhala S, Moore PK: Role of hydrogen sulphide in haemorrhagic shock in the rat: protective effect of inhibitors of hydrogen sulphide biosynthesis. Br J Pharmacol 2004, 143:881-889.

160. McDonald MC, Mota-Filipe $H$, Wright JA, Abdelrahman M, Threadgill MD, Thompson AS, Thiemermann C: Effects of 5aminoisoquinolinone, a water-soluble, potent inhibitor of the activity of poly (ADP-ribose) polymerase on the organ injury and dysfunction caused by haemorrhagic shock. Br J Pharmacol 2000, 130:843-850.

161. Fink MP, Macias CA, Xiao J, Tyurina YY, Delude RL, Greenberger JS, Kagan VE, Wipf P: Hemigramicidin-TEMPO conjugates: novel mitochondria-targeted antioxidants. Crit Care Med 2007, 35:S461-S467.

162. Peckham RM, Handrigan MT, Bentley TB, Falabella MJ, Chrovian $A D$, Stahl GL, Tsokos GC: C5-blocking antibody reduces fluid requirements and improves responsiveness to fluid infusion in hemorrhagic shock managed with hypotensive resuscitation. J Appl Physiol 2007, 102:673-680.

163. Chaudry IH, Samy TS, Schwacha MG, Wang P, Rue LW, III, Bland $\mathrm{KI}$ : Endocrine targets in experimental shock. J Trauma 2003, 54:S118-S125.

164. Choudhry MA, Schwacha MG, Hubbard WJ, Kerby JD, Rue LW, Bland KI, Chaudry IH: Gender differences in acute response to trauma-hemorrhage. Shock 2005, 24(suppl 1):101-106.

165. Angele MK, Frantz MC, Chaudry IH: Gender and sex hormones influence the response to trauma and sepsis - potential therapeutic approaches. Clinics 2006, 61:479-488.

166. Choudhry MA, Bland KI, Chaudry IH: Trauma and immune response - effect of gender differences. Injury 2007, 38:18821391.

167. Choudhry MA, Chaudry IH: $17 \beta$-estradiol: a novel hormone for improving immune and cardiovascular responses following trauma-hemorrhage. J Leukoc Bio/ 2008, 183:518-522.

168. Wichmann MW, Angele MK, Ayala A, Cioffi WG, Chaudry IH: Flutamide: a novel agent for restoring the depressed cell- mediated immunity following soft-tissue trauma and hemorrhagic shock. Shock 1997, 8:242-248.

169. Angele MK, Wichmann MW, Ayala A, Cioffi WG, Chaudry IH: Testosterone receptor blockade after hemorrhage in males: Restoration of the depressed immune functions and improved survival following subsequent sepsis. Arch Surg 1997, 132:1207-1214.

170. Jarrar D, Kuebler JF, Wang P, Bland KI, Chaudry IH: DHEA: a novel adjunct for the treatment of male trauma patients. Trends Mol Med 2001, 7:80-85.

171. Jarrar D, Wang P, Song GY, Knoferl MW, Cioffi WG, Bland KI, Chaudry $\mathrm{IH}$ : Metoclopramide: a novel adjunct for improving cardiac and hepatocellular functions after trauma-hemorrhage and resuscitation. Am J Physiol 2000, 278:E90-E96.

172. Zellweger R, Zhu XH, Wichmann MW, Ayala A, DeMaso CM, Chaudry $\mathrm{IH}$ : Prolactin administration following hemorrhagic shock improves macrophage cytokine release capacity and decreases mortality from subsequent sepsis. J Immuno/ 1996, 157:5748-5754.

173. Zellweger R, Wichmann MW, Ayala A, DeMaso CM, Chaudry IH: Prolactin: a novel and safe immuno-modulating hormone for the treatment of immunodepression following severe hemorrhage. J Surg Res 1996, 63:53-58.

174. Kuebler JF, Jarrar D, Bland KI, Rue L, III, Wang P, Chaudry IH: Progesterone administration following trauma-hemorrhage in females with decreased sex steroids improves cardiovascular responses. Crit Care Med 2003, 31:1786-1793. 